\title{
Ecosystem services of restored oyster reefs in a Chesapeake Bay tributary: abundance and foraging of estuarine fishes
}

\author{
Bruce W. Pfirrmann ${ }^{1,2, *}$, Rochelle D. Seitz ${ }^{1}$ \\ ${ }^{1}$ Virginia Institute of Marine Science, William \& Mary, PO Box 1346, Gloucester Point, VA 23062, USA \\ ${ }^{2}$ Present address: Baruch Marine Field Laboratory, University of South Carolina, PO Box 1630, Georgetown, SC 29442, USA
}

\begin{abstract}
Restoration of oyster reefs in coastal ecosystems may enhance fish and fisheries by providing valuable refuge and foraging habitat, but understanding the effects of restoration requires an improved understanding of fish habitat use and trophic dynamics, coupled with longterm ( $>5 \mathrm{yr}$ ) monitoring of restored habitats. We evaluated the relationship between large (3-5 ha) restored subtidal oyster reefs and mobile estuarine fishes in the Lynnhaven River System (LRS), Virginia, more than 8 yr following reef construction. We compared the (1) diversity, (2) abundance, (3) size, (4) stomach fullness, (5) diet composition, and (6) daily consumption rate of fishes collected from restored oyster reefs with those from an area of unstructured, unrestored bottom, via experimental gill nets. We sampled monthly from April to October 2016 and conducted $24 \mathrm{~h}$ sampling in July and September 2016. Community composition was similar between habitats, dominated by spot Leiostomus xanthurus, Atlantic menhaden Brevoortia tyrannus, silver perch Bairdiella chrysoura, and Atlantic croaker Micropogonias undulatus. Abundance in reef habitat was significantly reduced relative to unstructured bottom, but the mean length of fishes collected from reefs was significantly greater than that of unstructured bottom. In addition, the estimated consumption rate of silver perch foraging in reef habitat significantly exceeded that of silver perch foraging in unstructured bottom. Nearly a decade post-restoration, restored reefs in the LRS are used by a similar assemblage as unrestored areas, but the manner of use differs by species and size. Considering a broad range of responses is necessary to evaluate the impacts of oyster restoration on mobile fishes.
\end{abstract}

KEY WORDS: Oyster restoration $\cdot$ Chesapeake Bay $\cdot$ Fish habitat $\cdot$ Ecosystem service $\cdot$ Diet composition $\cdot$ Consumption rate

\section{INTRODUCTION}

The dramatic loss of reefs created by the eastern oyster Crassostrea virginica in the United States (over $95 \%$ in some estuaries) has prompted widespread interest in oyster reef restoration (Beck et al. 2011). Beyond increasing local oyster populations, oyster reef restoration is hypothesized to enhance ecosystem services such as nutrient cycling, shoreline protection, and fish production (Coen et al. 2007).

\footnotetext{
${ }^{*}$ Corresponding author: bruce@baruch.sc.edu
}

Oyster reefs can support fisheries productivity via the provision of structured habitat, much like salt marshes or seagrass beds, in estuaries otherwise dominated by unstructured soft-sediments (Beck et al. 2001, zu Ermgassen et al. 2016). The survival of many fish species is positively associated with increased structural complexity and the presence of predator refuge (Stunz \& Minello 2001, Scharf et al. 2006). The combination of hard substrate and interstitial space provided by oyster reefs also serves to promote the settlement, growth, and survival of ben-

() The authors 2019. Open Access under Creative Commons by Attribution Licence. Use, distribution and reproduction are unrestricted. Authors and original publication must be credited. 
thic invertebrates and resident fishes at high densities (Rodney \& Paynter 2006, Karp et al. 2018). Improved foraging success stemming from the increased prey availability may enhance fish growth and result in a gain of nekton biomass (Powers et al. 2003).

Both natural and restored oyster reefs can be associated with increased catch rates and enhanced abundance of juvenile and adult fishes, particularly in comparison with unstructured bottoms (Lenihan et al. 2001, Humphries \& La Peyre 2015). Habitat use of oyster reefs by mobile fishes is dynamic and contextdependent, however, and the abundance of fish associated with reefs can vary with changing environmental conditions, reef structure and orientation, and the proximity of reefs to other habitats (Geraldi et al. 2009, Harwell et al. 2011). In addition to these variables, the relationship between restored oyster reefs and fish may be influenced by time since restoration, as changes in reef structure and the associated faunal community can affect the composition and dynamics of the fishes utilizing oyster reefs (La Peyre et al. 2014, Ziegler et al. 2018). The majority of restoration monitoring studies are conducted within a 3 yr window post-construction, and few are conducted more than 5 yr post-construction (Borja et al. 2010, Zhao et al. 2016).

Given the known variability in fish abundance observed in association with restored oyster reefs, evaluating habitat-related trophic dynamics may shed additional light on the functional role that restored oyster reefs play within a given coastal system. For instance, if oyster reefs enhance fish growth or productivity, consumption of reef-associated benthic macrofauna and resident fishes ought to represent a strong trophic pathway connecting oyster reefs to higher trophic levels, regardless of the number of fishes utilizing the habitat at any particular moment (Peterson et al. 2000). A trophic-oriented approach is also relevant in light of efforts to implement ecosystem-based fisheries management (EBFM), which necessitates an improved understanding of trophic linkages and the forage base of key fishery species (Ihde et al. 2015).

The diet and trophic ecology of fishes associated with oyster reefs is less well studied than fish abundance and density, but some functional links between oyster reefs and mobile fishes have been established. In Florida, over half of juvenile grey snapper Lutjanus griseus diet by weight was comprised of reefaffiliated organisms, including benthic mud crabs and reef-resident fishes (Yeager \& Layman 2011). Striped bass Morone saxtilis and bluefish Pomatomus saltatrix consumed more teleost fish prey around a restored oyster reef than an unstructured bottom in the Piankatank River, Virginia, suggesting that oyster reef habitat use facilitated improved foraging opportunities on energetically rich fish prey (Harding \& Mann 2001a, 2003). Connecting the diet of fishes using restored reefs as habitat together with estimates of reef-associated consumption would also pave the way for process-based model estimates of oyster-reef fish production. Bioenergetics models incorporating these parameters are beginning to be developed (McCoy et al. 2017), yet these models require empirical field data, much of which remains to be collected.

The overall objective of this study was to evaluate the effects of restored subtidal oyster reefs, constructed nearly a decade prior in a sub-estuary of the Chesapeake Bay, on the abundance and foraging patterns of mobile estuarine fishes. Specifically, we compared the (1) diversity, (2) abundance, (3) size, (4) stomach fullness, (5) diet composition, and (6) daily consumption rate of fishes collected from restored oyster reef habitat with those from unstructured bottom habitat in the Lynnhaven River System (LRS), Virginia. We hypothesized that fish abundance in oyster reef habitat would either equal or exceed that of the reference, unstructured habitat, and we anticipated equal or higher levels of stomach fullness in reef-caught fishes. We also expected the frequent occurrence of reef-associated macrofauna and reefresident fishes in the diet of oyster reef-caught fishes.

\section{MATERIALS AND METHODS}

\subsection{Study location and site selection}

The LRS is small sub-estuary of Chesapeake Bay located near Virginia Beach, Virginia, USA, with a mean river depth of $2.5 \mathrm{~m}$ (Lawless \& Seitz 2014, Fig. 1). In 2007 and 2008, the US Army Corps of Engineers constructed a relatively large-scale reef complex of 12 oyster reefs totaling 20.57 ha in Broad Bay and Linkhorn Bay, segments of the LRS (Lipcius et al. 2015). We conducted our study using 3 replicate restored oyster reef and 3 replicate unstructured softbottom (hereafter, control) sites ( $\mathrm{n}=6$ sites total; Fig. 1). All restored reefs were subtidal, closed to oyster harvest, supported average oyster densities of 59.8 ind. $\mathrm{m}^{-2}$, and ranged in depth from 1.2-3.5 m (Table 1) (Lipcius et al. 2015). We used ArcGIS 10.3 (ESRI) to select control sites within a similar depth range that were located at least $750 \mathrm{~m}$ distant from 
Fig. 1. Study location and sample sites in the Lynnhaven River System, Virginia, USA. Stars: restored oyster reef sites; circles: unstruc-

tured bottom control sites

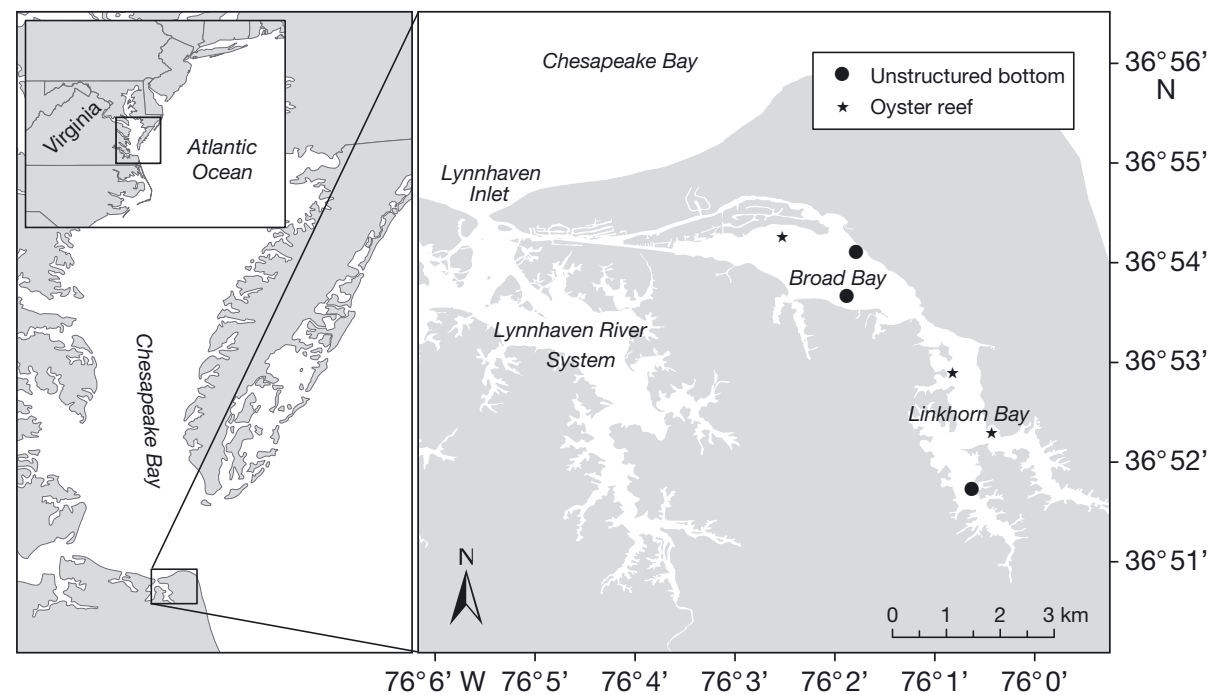

Table 1. Restored oyster reef site characteristics in the Lynnhaven River System. Oyster density, oyster biomass, and reef area information obtained from Lipcius et al. (2015). Mean depth refers to the average depth of gill net sets on each reef, as determined via boat-mounted depth finder

\begin{tabular}{|lcccc|}
\hline Site & $\begin{array}{c}\text { Oyster } \\
\text { density } \\
\left(\mathrm{m}^{-2}\right)\end{array}$ & $\begin{array}{c}\text { Oyster } \\
\text { biomass } \\
\left(\mathrm{g} \mathrm{m}^{-2}\right)\end{array}$ & $\begin{array}{r}\text { Reef } \\
\text { area } \\
(\text { ha })\end{array}$ & $\begin{array}{c}\text { Mean } \\
\text { depth } \\
(\mathrm{m})\end{array}$ \\
\hline Broad Bay Reef 3 & 55.4 & 31.1 & 4.9 & 1.8 \\
Linkhorn Bay Reef 1 & 49.3 & 42.0 & 3.2 & 2.7 \\
Linkhorn Bay Reef 2 & 74.8 & 117.5 & 5.7 & 2.8 \\
\hline
\end{tabular}

restored reef sites, using benthic habitat data provided by the National Oceanographic and Atmospheric Administration's (NOAA) Chesapeake Bay Office.

\subsection{Monthly fish survey}

We evaluated fish abundance and collected fish stomach content samples using experimental gill nets. Sampling was conducted once in April, once in May, and 2-3 times $\mathrm{mo}^{-1}$ from June to October 2016. We fished all 6 sites ( 3 restored reefs, 3 control) on each sampling date with one gill net (restored reef, $\mathrm{n}=45$; control, $\mathrm{n}=44$ ). The order in which gill nets were deployed among sites was randomized each sampling date. The monofilament gill nets were sinking-rigged and designed to fish the lower $50-100 \%$ of the water column. Each net measured $45.7 \mathrm{~m}$ long $\times 1.8 \mathrm{~m}$ deep and was partitioned into 3 panels of mesh size 3.18, 7.62, and $12.7 \mathrm{~cm}$ (stretch). We fished the nets perpendicular to tidal flow during daytime hours (approximately 09:00-18:00 h), and recorded tidal stage (flood, ebb, slack) at the start of each net set. At oyster reef sites, gill nets were set directly above the reefs, within the reef boundaries delineated by benthic mapping data provided by NOAA. Temperature $\left({ }^{\circ} \mathrm{C}\right)$, dissolved oxygen $\left(\mathrm{mg} \mathrm{l}^{-1}\right)$, and salinity (psu) were recorded at the start of each net set using a handheld water quality probe (YSI Professional Plus). Gill net sets were limited to approximately $1.5 \mathrm{~h}$ to decrease the likelihood of stomachcontent evacuation by captured fish (Sutton et al. 2004).

Upon net retrieval, all collected fish were removed from the gill nets. Up to 25 individuals from a given species and size class were euthanized in an ice slurry and kept on ice for laboratory processing. Sizeclass determinations were based on mesh size of capture. Additional fish were identified and counted before being released. All sampling in this study was conducted in accordance with William \& Mary's Institutional Animal Care and Use Committee (Protocol \#: IACUC-2014-09-17-9772-rdseit).

In the lab, all retained individuals were identified, counted, measured (total length, TL [mm]) and weighed (nearest $0.1 \mathrm{~g}$, wet weight). Stomachs of up to 5 individuals per species, size class, and net set were removed and placed in isotonic fixative (Norma$\operatorname{lin}^{\mathrm{TM}}$ ) for preservation and eventual diet analysis. At a later date, these stomachs were then removed from isotonic fixative, rinsed, and individually weighed (nearest $0.001 \mathrm{~g}$ ). Stomachs were emptied, all contents rinsed with ethanol $(70 \%)$ into a clear plastic petri dish, and the empty stomachs weighed again. Prey items were sorted, identified to lowest taxonomic level, and weighed together by taxa (nearest $0.001 \mathrm{~g}$ ). 


\section{3. $24 \mathrm{~h}$ fish survey}

We conducted two $24 \mathrm{~h}$ sampling events (19-20 July and 27-28 September 2016) to evaluate stomach fullness trends and estimate daily consumption rates. We selected one restored oyster reef and one control site within Broad Bay and visited the same 2 sites in July and September. During each sampling event, 3 gill nets were set at each site (reef and control) for approximately $2.5 \mathrm{~h}$ at a time; we used additional gill nets and lengthened soak times relative to the monthly survey in an attempt to increase catch and sample size. Upon net retrieval, all collected organisms were removed from the gill nets and the nets were reset and fished again. Up to 10 individuals from a given species and size class were euthanized in an ice slurry and kept on ice for laboratory processing, preservation, and later diet analysis. We recorded tidal stage and water quality conditions at the start of each net set. Gill net retrieval times did not overlap precisely between habitat types or between months (e.g. due to large catches or weather-related delays), so the gill net sets were partitioned into six 4 $\mathrm{h}$ time blocks for subsequent analyses (09:00-13:00, 13:00-17:00, 17:00-21:00, 21:00-01:00, 01:00-05:00, 05:00-09:00 h).

\subsection{Fish diversity, abundance, and size analysis}

We used permutational multivariate analysis of variance (PERMANOVA), which allows for the significance testing of differences between groups using distance matrices (Anderson 2001), to test for differences in overall community composition between the 2 habitat types. A 1-way PERMANOVA test was con- ducted using a Bray-Curtis dissimilarity matrix generated from a species abundance matrix (at the gill net set level). Statistical significance was set at $\alpha=$ 0.1. PERMANOVA calculations were conducted using the statistical program R and the R package 'vegan' (R Core Team 2016, Oksanen et al. 2019).

We modeled fish abundance during the monthly survey using generalized linear models (GLMs) and generalized linear mixed models (GLMMs; Venables \& Dichmont 2004). We examined 2 responses: (1) total fish catch and (2) species-specific catch, for the most abundant non-filter-feeding fishes: Leiostomus xanthurus (spot), Bairdiella chrysoura (silver perch), and Micropogonias undulatus (Atlantic croaker); all members of the Sciaenidae (drum) family. For each response, we chose number of fish captured per gill net set as the dependent variable. A negative binomial distribution was assumed for all models and employed together with a log-link function. Fishing effort (gill net soak time) was incorporated via an offset term included in all models (Maunder \& Punt 2004). April and May sampling events (2 d, 12 net sets) were excluded from the statistical analysis due to low catch size (4 ind. collected total). We constructed 10 candidate models (Table 2) to evaluate the influence of habitat type (discrete variable; restored reef or control). Models also incorporated environmental variables hypothesized to influence fish catch, including month (discrete variable; June through October), water temperature (continuous variable), salinity (continuous variable), and tidal stage (discrete variable; flood, slack, ebb). Two GLMMs included sampling site as a random error term. We ran and fit all models using $R$ packages 'Ime4' and 'MASS' (Venables \& Ripley 2002, Bates et al. 2015).

Table 2. Candidate models for generalized linear and generalized linear mixed model analysis of fish relative abundance. $k$ : model degrees of freedom; $Z$ : random effect term included in 2 models; $T$ : water temperature

\begin{tabular}{|c|c|c|c|c|c|c|c|c|c|}
\hline \multirow[t]{2}{*}{ Model } & \multirow{2}{*}{$k$} & \multicolumn{8}{|c|}{ - Variables } \\
\hline & & Intercept & $\begin{array}{c}\boldsymbol{x}_{1} \\
\text { Habitat }\end{array}$ & $\begin{array}{c}x_{2} \\
\text { Month }\end{array}$ & $\begin{array}{c}x_{3} \\
\text { Tide }\end{array}$ & $\begin{array}{c}x_{4} \\
T\end{array}$ & $\begin{array}{c}x_{5} \\
\text { Salinity }\end{array}$ & $\begin{array}{c}x_{6} \\
\text { Habitat } \times \text { month }\end{array}$ & $\begin{array}{c}Z \\
\text { Site }\end{array}$ \\
\hline$g_{1}$ & 2 & $\beta_{0}$ & & & & & & & \\
\hline $\mathrm{g}_{2}$ & 3 & $\beta_{0}$ & $\beta_{1}$ & & & & & & \\
\hline$g_{3}$ & 7 & $\beta_{0}$ & $\beta_{1}$ & $\beta_{2}$ & & & & & \\
\hline$g_{4}$ & 11 & $\beta_{0}$ & $\beta_{1}$ & $\beta_{2}$ & & & & $\beta_{6}$ & \\
\hline$g_{5}$ & 5 & $\beta_{0}$ & $\beta_{1}$ & & $\beta_{3}$ & & & & \\
\hline $\mathrm{g}_{6}$ & 4 & $\beta_{0}$ & $\beta_{1}$ & & & $\beta_{4}$ & & & \\
\hline$g_{7}$ & 4 & $\beta_{0}$ & $\beta_{1}$ & & & & $\beta_{5}$ & & \\
\hline$g_{8}$ & 9 & $\beta_{0}$ & $\beta_{1}$ & $\beta_{2}$ & $\beta_{3}$ & & & & \\
\hline$g_{9}$ & 5 & $\beta_{0}$ & $\beta_{1}$ & & & $\beta_{4}$ & $\beta_{5}$ & & \\
\hline $\mathrm{g}_{10}$ & 8 & $\beta_{0}$ & $\beta_{1}$ & $\beta_{2}$ & & & & & $\mathrm{X}$ \\
\hline$g_{11}$ & 5 & $\beta_{0}$ & $\beta_{1}$ & & & $\beta_{4}$ & & & $\mathrm{X}$ \\
\hline
\end{tabular}


Fitted models (as well as an intercept-only null model) were compared using Akaike's information criterion (corrected for small sample size; $\mathrm{AIC}_{\mathrm{c}}$ ), which provides evidence regarding the likelihood of a certain model and rewards model parsimony by penalizing over-parameterized models (Burnham \& Anderson 2002). We evaluated model fit to the data and adherence of the data to model assumptions using diagnostic plots (residual values vs. fitted values; quantile-quantile plots) and diagnostic statistics (e.g. dispersion). Selection of a single 'top model' was informed by $\mathrm{AIC}_{\mathrm{c}}$ value and model fit to data, with a preference for parsimony. We considered parameter estimates statistically significant at the $\alpha=0.1$ level.

Because the abundance of Atlantic croaker was low throughout the sampling period, we instead chose to model the presence or absence of croaker in our gill net sets. We assumed a binomial distribution with a logit link function, employed the same suite of predictor variables as before, and selected a top model as described above.

We evaluated whether the size of fish utilizing restored oyster reef habitat and control habitat in the LRS differed using non-parametric Mann-Whitney $U$-tests. Specifically, we compared mean length (fish TL) for the overall catch (all collected individuals, pooled), silver perch, spot, and Atlantic croaker between habitat types, and considered parameter estimates statistically significant at the $\alpha=0.1$ level.

\subsection{Fish stomach fullness and diet composition}

Silver perch, spot, and Atlantic croaker were selected for analysis of stomach fullness and diet composition. We determined stomach fullness for individual fish captured during both the monthly survey and the $24 \mathrm{~h}$ survey as: total prey weight $(\mathrm{g})$ / fish wet weight $(\mathrm{g})$, where total prey weight equaled the sum of all individual prey items (including unidentified material; Facendola \& Scharf 2012). We averaged stomach fullness values from individual fish by gill net set to prevent pseudoreplication. We evaluated the effects of habitat type (reef or control) and month (June through October) on fish stomach fullness during the monthly survey, using GLMs. We also used GLMs to evaluate the effects of habitat type, time of day (six $4 \mathrm{~h}$ time blocks; see Section 2.3), and month (July or September) on fish stomach fullness during the $24 \mathrm{~h}$ survey. Stomach fullness values were log-transformed prior to modeling, and model results were compared using $\mathrm{AIC}_{\mathrm{C}}$.

For each species, we determined 2 diet indices for each prey taxa identified during the monthly survey: percent frequency occurrence $(\% F)$ and percent composition by weight ( $\% W$ ) (Buckel et al. 1999). Diet indices were determined using a cluster-sampling estimator that treats each gill net set ('cluster') as an independent replicate (Buchheister \& Latour 2015). Due to limited sample size, fish were pooled by species across size classes and month of sampling, and $\% F$ and $\% W$ calculated by habitat type. Prey taxa were grouped into 13 categories for analysis (see Table 6 legend). For a given species, the $\% F$ of prey type $k$ (percent of stomachs containing prey type $k$ ) was estimated as:

$$
\% F_{k}=\frac{\sum_{i=1}^{n} M_{i} p_{i k}}{\sum M_{i}} \cdot 100
$$

where $p_{i k}=\frac{m_{i k}}{m_{i}}$ and where $n=$ number of clusters that contain species $x, M_{i}=$ number of individuals of species $x$ collected in cluster $i, m_{i}=$ number of individuals in a subsample of species $x$ analyzed for diet from cluster $i$, and $m_{i k}=$ number of individuals in the subsample with food type $k$ in cluster $i$.

The $\% W$ of prey type $k$ was estimated for a given species as:

$$
\% W_{k}=\frac{\sum_{i=1}^{n} M_{i} q_{i k}}{\sum M_{i}} \cdot 100
$$

where $q_{i k}=\frac{W_{i k}}{W_{i}}$ and where $w_{i}=$ total weight of all identifiable prey in a subsample of the fish from cluster $i$ analyzed for diet, $w_{i k}=$ weight of prey type $k$ in the subsample from cluster $i$.

PERMANOVA tests were used to examine differences in overall diet composition between the 2 habitat types. For each species, 1-way PERMANOVA tests were conducted using Bray-Curtis dissimilarity matrices generated from $\% F$ and $\% W$ observations (calculated at the cluster level). Statistical significance was set at $\alpha=0.1$. If significant differences between habitat were indicated by PERMANOVA, similarity percentage (SIMPER) was used to identify the prey types contributing most prominently to betweengroup dissimilarity (Clarke \& Warwick 2001). PERMANOVA and SIMPER calculations were conducted using R package 'vegan' (Oksanen et al. 2019).

\subsection{Daily consumption rate estimates}

We used stomach fullness and environmental data collected during the $24 \mathrm{~h}$ survey to estimate individual daily consumption by habitat (reef and control) and month (July and September) for silver perch. We selected silver perch for this analysis due to its frequent occurrence in gill nets over the $24 \mathrm{~h}$ period. 
Individual daily consumption ( $\mathrm{g}$ of prey consumed $\mathrm{g}$ of predator ${ }^{-1} \mathrm{~d}^{-1}$ ) was estimated using a gastric evacuation model of the form $C_{d}=24 \cdot E_{i} \cdot \bar{S}_{i}{ }^{Y}$, where $\bar{S}_{i}{ }^{Y}$ is mean total stomach fullness of species $i, 24$ is the number of hours in a day, and $y$ is a constant, typically set equal to 1 (Link et al. 2002). The gut evacuation rate $E\left(\mathrm{~h}^{-1}\right)$ is given by $E_{i}=\alpha \cdot \mathrm{e}^{\beta \cdot T_{p}}$, where $\alpha$ and $\beta$ are constants and $T_{p}$ is average daily temperature. Standard values of $\alpha$ and $\beta$ in the literature are 0.004 and 0.115, respectively (Link et al. 2002). This model assumes that fish feed continuously at a constant rate, but stomach samples collected over sufficiently short time periods can yield reasonably unbiased consumption estimates if this assumption is not met (Durbin et al. 1983).

Stomach fullness values from individual fish were first averaged by $4 \mathrm{~h}$ sampling period, resulting in 6 separate estimates of stomach fullness per habitatmonth combination. We then averaged all 6 estimates to obtain a daily average value of stomach fullness. We set $T_{p}$ to the mean water temperature recorded in situ during sampling (July $T_{p}=29.9^{\circ} \mathrm{C}$; September $T_{p}=24.6^{\circ} \mathrm{C}$ ). Because the applicability of $\alpha$ and $\beta$ to silver perch is not known, we chose to add variability to our estimate. Unique values for $\alpha$ and $\beta$ (1000 of them) were selected randomly from uniform distributions with a range of $0.5-1.5 \times$ the standard literature value, and a consumption estimate derived for each habitat-month combination. We determined mean daily consumption by taking the average of the set of 1000 estimates, and standard error by determining the standard deviation of the 1000 estimates. For each month, we compared the mean estimate of daily consumption between habitat types using MannWhitney $U$-tests. We then converted mean daily consumption estimates from each habitat and month into consumption per individual ( $\mathrm{g}$ of prey consumed fish $^{-1} \mathrm{~d}^{-1}$ ) by multiplying the consumption estimate by the mean wet weight of fish collected in that month $($ July $=26.4 \mathrm{~g}$; September $=22.9 \mathrm{~g})$.

\section{RESULTS}

\subsection{Environmental conditions}

Water temperatures increased steadily from April to August before declining in September and October $\left(\right.$ mean $=25.6^{\circ} \mathrm{C}$; range $=17.0-31.7^{\circ} \mathrm{C}$; Table S1 in the Supplement at www.int-res.com/articles/suppl/ m628p155_supp.pdf). Polyhaline salinity conditions persisted throughout the majority of the study (mean = $22.8 \mathrm{psu}$; range $=15.5-26.2 \mathrm{psu}$ ), though reduced salinity was observed in October following heavy rainfall (mean $=18.0$ psu; range $=15.5-21.2 \mathrm{psu}$ ). Dissolved oxygen remained normoxic throughout the study period $\left(\right.$ mean $=6.9 \mathrm{mg} \mathrm{l}^{-1}$; range $=4.1-9.0 \mathrm{mg}$ $\left.\mathrm{l}^{-1}\right)$, suggesting any observed patterns in fish abundance and diet would not be the result of physiologically stressful low-oxygen conditions.

Table 3. Mean (SE) catch per unit effort (CPUE; no. of fish caught $\mathrm{h}^{-1}$ in gill net sets), total length (TL), and total number of individuals (n) of all fish species collected via gill nets from restored oyster reefs and control sites in the Lynnhaven River System during a monthly survey (April-October 2016). Total number of gill net sets: reef $=45$; control $=44$

\begin{tabular}{|c|c|c|c|c|c|c|}
\hline & \multicolumn{3}{|c|}{ Oyster reef } & \multicolumn{3}{|c|}{-Control- } \\
\hline & CPUE & $\mathrm{TL}(\mathrm{mm})$ & $\mathrm{n}$ & CPUE & TL (mm) & $\mathrm{n}$ \\
\hline Leiostomus xanthurus (spot) & $3.57(0.98)$ & $109.0(1.2)$ & 308 & $5.90(2.52)$ & $108.4(0.7)$ & 453 \\
\hline Brevoortia tyrannus (Atlantic menhaden) & $3.78(0.80)$ & $160.1(4.5)$ & 324 & $4.03(0.82)$ & $120.9(2.5)$ & 325 \\
\hline Bairdiella chrysoura (silver perch) & $0.81(0.32)$ & $129.6(1.0)$ & 73 & $0.44(0.14)$ & $124.9(1.5)$ & 34 \\
\hline Micropogonias undulatus (Atlantic croaker) & $0.27(0.06)$ & $246.1(11.7)$ & 24 & $0.30(0.08)$ & $188.6(12.7)$ & 23 \\
\hline Opisthonema oglinum (Atlantic thread herring) & $0.21(0.15)$ & $120.1(1.3)$ & 17 & $0.25(0.16)$ & $120.2(1.6)$ & 17 \\
\hline Mugil sp. (mullet sp.) & $0.09(0.07)$ & $134.5(1.5)$ & 8 & $0.18(0.13)$ & $130.6(1.3)$ & 15 \\
\hline Dorosoma cepedianum (gizzard shad) & $0.08(0.04)$ & $208.5(29.0)$ & 6 & $0.21(0.06)$ & $280.7(23.6)$ & 15 \\
\hline Pomatomus saltatrix (bluefish) & $0.08(0.04)$ & $334.2(40.1)$ & 6 & $0.06(0.03)$ & $338.2(59.3)$ & 5 \\
\hline Prionotus carolinus (northern sea robin) & $0.04(0.02)$ & $136.8(5.6)$ & 4 & $0.02(0.02)$ & $128.0(12.0)$ & 2 \\
\hline Cynoscion nebulosus (speckled trout) & $0.01(0.01)$ & $335.0(-)$ & 1 & $0.03(0.02)$ & $207.5(82.5)$ & 2 \\
\hline Cynoscion regalis (weakfish) & $0.03(0.02)$ & $248.0(58.0)$ & 2 & $0.02(0.02)$ & $183.0(-)$ & 1 \\
\hline Brama brama (Atlantic pomfret) & - & - & 0 & $0.02(0.02)$ & 182.5 & 1 \\
\hline Lagodon rhomboides (pinfish) & $0.01(0.01)$ & $149.0(-)$ & 1 & $0.02(0.02)$ & 158.0 & 1 \\
\hline Eucinostomus argenteus (spotfin mojarra) & - & - & 0 & $0.01(0.01)$ & 126.0 & 1 \\
\hline Menticirrhus saxatilis (northern kingfish) & $0.01(0.01)$ & $310.0(-)$ & 1 & - & - & 0 \\
\hline Pogonias cromis (black drum) & - & - & 0 & $0.01(0.01)$ & 213.0 & 1 \\
\hline Overall & $10.4(1.45)$ & $142.5(2.5)$ & 775 & $13.3(3.22)$ & $123.8(1.8)$ & 897 \\
\hline
\end{tabular}




\subsection{Fish diversity, abundance, and size}

In total, 1672 individuals from 16 different species (15 from control habitat, 13 from oyster reef habitat) were collected from April to October 2016 (Table 3). Spot, Atlantic menhaden (Brevoortia tyrannus), silver perch, and Atlantic croaker were the 4 most abundant species captured and comprised over $90 \%$ of the total catch. Overall community composition did not vary significantly by habitat type (1-way PERMANOVA pseudo- $\mathrm{R}^{2}=$ $0.05, F=0.28, p=0.92$ ). Overall catch per unit effort (CPUE) increased from spring to mid-summer in both habitat treatments, reaching a July peak in oyster reef habitat and an August peak in control habitat (Fig. 2a). CPUE in both habitats declined in September and again in October. Water temperature was positively associated with overall CPUE in the most likely GLM (estimate $=0.16, Z=-1.83$, $\mathrm{p}=0.07$; Tables S2 \& S3), and overall CPUE was significantly lower in oyster reef habitat compared to control habitat (estimate $=-0.33, Z=6.27, \mathrm{p}<0.01$ ).

We evaluated species-specific catch rates for spot, silver perch, and Atlantic croaker, the 3 most abundant benthic-feeding fishes. Spot CPUE followed a pattern similar to overall CPUE, increasing from

Table 4. Mean (SE) size (total length, TL) of all fishes, silver perch Bairdiella chrysoura, spot Leiostomus xanthurus, and Atlantic croaker Micropogonias undulatus collected from restored oyster reefs and control sites, and results of MannWhitney $U$-tests comparing size distributions between habitat types. Bold indicates statistically significant comparisons ( $\alpha=0.1$ level)

\begin{tabular}{|lcccc|}
\hline \multirow{2}{*}{$\begin{array}{l}\text { Species/ } \\
\text { Group }\end{array}$} & \multicolumn{2}{c}{ TL (mm) } & \multicolumn{2}{c|}{ Mann-Whitney $U$-test } \\
& Oyster reef & Control & $W$ & p-value \\
\hline $\begin{array}{l}\text { All fishes } \\
\text { combined }\end{array}$ & 142.5 & 123.8 & 283550 & $<\mathbf{0 . 0 0 1}$ \\
Silver perch & 129.6 & $(1.8)$ & & \\
& $(1.0)$ & $(1.5)$ & & \\
Spot & 109.0 & 108.4 & 32804 & $\mathbf{0 . 0 4 7}$ \\
& $(1.2)$ & $(0.7)$ & & \\
Atlantic & 246.1 & 188.6 & 408 & $<\mathbf{0 . 0 0 1}$ \\
croaker & $(11.7)$ & $(12.7)$ & & \\
\hline
\end{tabular}

April to August before declining in both September and October (Fig. 2b). Water temperature exhibited a significant positive relationship with spot CPUE (estimate $=0.29, Z=7.08, \mathrm{p}<0.01$ ), and the relationship between oyster reef habitat and spot CPUE was negative (estimate $=-0.49, \mathrm{Z}=-1.86, \mathrm{p}=0.06$ ). Silver perch were collected at low levels of abundance (mean CPUE $<2$ fish $^{-1}$ ) over the study period (Fig. 2c). We did not capture silver perch at control sites in September, and mean oyster reef CPUE exceeded control CPUE in July. No model performed better than the intercept-only model, and a relationship between habitat type and silver perch abundance was not discernable with our data (Tables S2 \& S3). Overall CPUE for Atlantic croaker was lowest among the 3 sciaenids examined and did not exceed $1 \mathrm{fish} \mathrm{h}^{-1}$ for either habitat type (Fig. 2d). Month was a significant explanatory variable in the top model for Atlantic croaker presence-absence (Tables S2 \& S3). For both habitat types, croaker were significantly less likely to occur in September or October (September estimate $=$ $-2.49, Z=-2.64, \mathrm{p}<0.01$; October estimate $=-3.71$, $Z=-3.02, \mathrm{p}<0.01)$ compared to the summer months (June, July, August).

We found statistically significant differences $(\mathrm{p}<$ 0.1 ) in mean TL between habitat types (Table 4). Specifically, the TL of fish collected from oyster reefs exceeded that of control habitat for all 4 comparisons 
Table 5. Number of gill net sets that included fish, number of individuals sampled, and size range (total length, TL) of fish examined for stomach contents by species and habitat type in the monthly survey. Total number of gill net sets during monthly survey: reef $=45$; control $=44$

\begin{tabular}{|llccc|}
\hline Species & Habitat & $\begin{array}{c}\text { Sets } \\
\text { with fish }\end{array}$ & $\begin{array}{c}\text { No. of fish } \\
\text { sampled }\end{array}$ & $\begin{array}{c}\text { TL range } \\
\text { (mm) }\end{array}$ \\
\hline $\begin{array}{llccc}\text { Silver } \\
\text { perch }\end{array}$ & Control & 14 & 28 & $109-152$ \\
Reef & 22 & 43 & $111-159$ \\
& Control & 34 & 113 & $92-230$ \\
Atlantic & Reef & 33 & 114 & $93-234$ \\
croaker & Reef & 18 & 22 & $106-330$ \\
& & 15 & 24 & $113-315$ \\
\hline
\end{tabular}

(all fishes combined, spot, silver perch, and Atlantic croaker). Differences in mean length ranged from nearly $60 \mathrm{~mm}$ (Atlantic croaker) to $<1 \mathrm{~mm}$ (spot).

\subsection{Fish stomach fullness and diet composition}

Both the number and size range of fish examined for stomach fullness and diet varied by species (Table 5). Spot were the most common, followed by silver perch and Atlantic croaker; Atlantic croaker tended to be the largest individuals, followed by silver perch and spot (Table 5). The effect of habitat type on mean stomach fullness varied by species and survey duration (monthly or 24 h; Fig. 3, Tables S4-

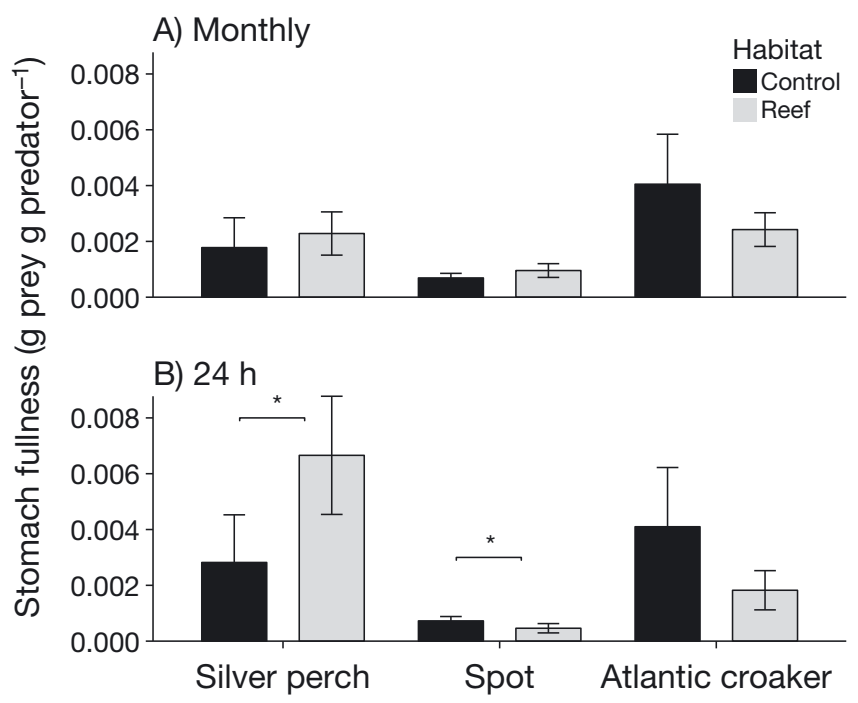

Fig. 3. Mean $( \pm 1 \mathrm{SE})$ stomach fullness of silver perch Bairdiella chrysoura, spot Leiostomus xanthurus, and Atlantic croaker Micropogonias undulatus by habitat type observed during the (A) monthly survey and (B) $24 \mathrm{~h}$ survey. $\left({ }^{*}\right)$ indicates habitat type was a significant $(\alpha=0.1)$ predictor of stomach fullness in the most likely generalized linear model
S7). Silver perch displayed a trend toward higher levels of mean stomach fullness in oyster reef habitat compared to control habitat during the monthly survey (Fig. 3a; reef mean $=0.0023 \mathrm{~g}$ of prey consumed $\mathrm{g}$ of predator ${ }^{-1}$; control mean $=0.0018 \mathrm{~g}$ prey g predator $\left.^{-1}\right)$, but habitat type was not a significant parameter in the most likely GLM (parameter estimate = $0.65, t=0.99, \mathrm{p}=0.33$ ). Habitat type was a significant predictor of mean stomach fullness in silver perch during the $24 \mathrm{~h}$ survey, and oyster reef individuals exhibited significantly higher levels of gut fullness than control individuals (Fig. $3 \mathrm{~b}$; reef mean $=0.007 \mathrm{~g}$ prey $\mathrm{g}$ predator $^{-1}$, control mean $=0.003 \mathrm{~g}$ prey $\mathrm{g}$ predator $^{-1}$; parameter estimate $=1.33, t=2.04, \mathrm{p}=$ $0.05)$. Mean stomach fullness of reef-caught spot during the monthly survey tended to be greater than control-caught spot (reef mean $=0.009 \mathrm{~g}$ prey g predator $^{-1}$, control mean $=0.007 \mathrm{~g}$ prey $\mathrm{g}$ predator ${ }^{-1}$ ), but this effect was not significant in the most likely GLM (Fig. 3a; estimate $=-0.102, t=-0.382, \mathrm{p}=0.7$ ). During the $24 \mathrm{~h}$ survey, however, oyster reef individuals displayed significantly lower values of mean stomach fullness relative to control fish (Fig. $3 \mathrm{~b}$; control mean = $0.0007 \mathrm{~g}_{\text {prey }} \mathrm{g}$ predator ${ }^{-1}$; reef mean $=0.005 \mathrm{~g}$ prey g predator ${ }^{-1}$; parameter estimate $=-0.61, t=-2.11, \mathrm{p}$ $=0.05)$. Spot collected during the second $24 \mathrm{~h} \mathrm{sam-}$ pling event in September also exhibited significantly lower mean stomach fullness values than did fish collected in July (July mean $=0.0009 \mathrm{~g}$ prey $\mathrm{g}$ predator $^{-1}$; September mean $=0.0002 \mathrm{~g}$ prey $\mathrm{g}$ predator ${ }^{-1}$; parameter estimate $=-1.39, t=-4.81, \mathrm{p}<0.01$ ). For Atlantic croaker, mean oyster reef stomach fullness tended to be less than mean control stomach fullness in both the monthly and $24 \mathrm{~h}$ survey data (Fig. 3a,b; monthly reef mean $=0.002 \mathrm{~g}$ prey $\mathrm{g}$ predator $^{-1}$; monthly control mean $=0.004 \mathrm{~g}$ prey $\mathrm{g}$ predator ${ }^{-1} ; 24$ $\mathrm{h}$ reef mean $=0.002 \mathrm{~g}$ prey $\mathrm{g}$ predator ${ }^{-1} ; 24 \mathrm{~h}$ control mean $=0.004 \mathrm{~g}$ prey $\mathrm{g}$ predator ${ }^{-1}$ ). Intercept-only models performed better than the models including habitat type (Tables S4 \& S6), and habitat type was not a significant parameter in the top non-intercept only model for either the monthly survey (estimate $=$ $-0.087, t=-0.147, \mathrm{p}=0.88$ ) or $24 \mathrm{~h}$ survey (estimate $=$ $-0.66, t=-1.00, \mathrm{p}=0.34$ ).

Silver perch fed most frequently on polychaete worms and snapping shrimp Alpheus heteorchaelis in oyster reef habitat ( $\% F>10$; Table 6$)$. These 2 prey items also dominated the bulk of the diet of oyster reef individuals by weight. Other prey, including mysid shrimps (primarily opossum shrimp Neomysis americana), fishes (including naked goby Gobiosoma bosc), and unidentified crustaceans were encountered infrequently in oyster reef $\operatorname{diets}(\% F<10)$. 
Table 6. Mean (SE) percent by weight $(\% W)$ and frequency of occurrence $(\% F)$ of major prey types in the stomachs of silver perch Bairidella chrysoura, spot Leiostomus xanthurus, and Atlantic croaker Micropogonias undulatus during a monthly survey, estimated by habitat type in order of highest percentage weight across both habitats. Prey categories: amphipod/isopod (all amphipod/isopods); bivalve (all non-clam bivalves, whole or pieces, including shell only if attached to tissue); blue crab Callinectes sapidus; clam (all clams, including shell only if attached to tissue); copepod (primarily benthic copepods, Harpacticoida); crustacean (all other crustaceans not detailed, or unidentifiable pieces); fishes (all teleost fishes, identified and unidentified, except Gobiosoma bosc); goby G. bosc; mysid Neomysis sp.; shrimps (includes Crangon sp., Palaeomentes sp., and unidentified shrimps); snapping shrimp Alpheus heterochaelis; tunicate Molgula sp.; unidentified (prey material too degraded to adequately classify); (-) not found

\begin{tabular}{|c|c|c|c|c|c|}
\hline \multirow{2}{*}{ Species } & \multirow{2}{*}{ Prey } & \multicolumn{2}{|c|}{$\% W$} & \multirow{2}{*}{ Reef } & \multirow[b]{2}{*}{ Control } \\
\hline & & Reef & Control & & \\
\hline \multirow[t]{11}{*}{ Silver perch } & Polychaete & $53.89(1.85)$ & $13.58(0.7)$ & $18.8(0.83)$ & $12.38(0.88)$ \\
\hline & Mysid & $4.4(0.15)$ & $35.75(1.86)$ & $4.02(0.18)$ & $25.71(1.82)$ \\
\hline & Snapping shrimp & $21.9(0.74)$ & - & $11.61(0.51)$ & - \\
\hline & Amphipod/isopod & - & $21.77(1.13)$ & - & $13.33(0.95)$ \\
\hline & Unidentified & $<0.01(0)$ & $14.32(0.75)$ & $2.17(0.1)$ & $8.57(0.61)$ \\
\hline & Fishes & $11.27(0.38)$ & $1.39(0.07)$ & $3.61(0.16)$ & $6.67(0.47)$ \\
\hline & Crustacean & $5.46(0.19)$ & $3.6(0.18)$ & $2.81(0.12)$ & $17.14(1.21)$ \\
\hline & Blue crab & - & $6.35(0.33)$ & - & $5.71(0.4)$ \\
\hline & Shrimps & $0.27(0.01)$ & $3.23(0.17)$ & $1.61(0.07)$ & $2.86(0.2)$ \\
\hline & Goby & $2.82(0.09)$ & - & $2.41(0.1)$ & - \\
\hline & Copepod & - & $<0.01$ & - & $2.86(0.2)$ \\
\hline \multirow[t]{10}{*}{ Spot } & Polychaete & $77.87(2.11)$ & $83.56(2.24)$ & $63.23(1.93)$ & $54.37(1.53)$ \\
\hline & Unidentified & $5.31(0.14)$ & $12.8(0.34)$ & $22.5(0.69)$ & $28.35(0.8)$ \\
\hline & Copepod & $6.11(0.16)$ & $2.16(0.06)$ & $43.4(1.32)$ & $22.85(0.64)$ \\
\hline & Tunicate & $7.54(0.2)$ & $<0.01(0)$ & $7.72(0.24)$ & $0.14(0)$ \\
\hline & Fishes & $2(0.05)$ & - & $0.65(0.02)$ & - \\
\hline & Mysid & $0.71(0.02)$ & $0.59(0.02)$ & $3.86(0.12)$ & $1.06(0.03)$ \\
\hline & Clam & $0.08(0)$ & $0.89(0.02)$ & $4.86(0.15)$ & $2.13(0.06)$ \\
\hline & Bivalve & $0.28(0.01)$ & - & $0.46(0.01)$ & - \\
\hline & Amphipod/isopod & $0.1(0)$ & $<0.01(0)$ & $2.23(0.07)$ & $1.48(0.04)$ \\
\hline & Crustacean & $<0.01(0)$ & $<0.01(0)$ & $2.12(0.06)$ & $0.14(0.01)$ \\
\hline \multirow[t]{9}{*}{ Atlantic croaker } & Polychaete & $67.05(3.47)$ & $60.98(3.88)$ & $56.82(3.12)$ & $73.98(4.89)$ \\
\hline & Bivalve & $5.04(0.26)$ & - & $22.73(1.26)$ & - \\
\hline & Clam & $9.56(0.49)$ & 30.78 (1.96) & $15.91(0.87)$ & $26.02(1.72)$ \\
\hline & Unidentified & $11.89(0.62)$ & $2.89(0.18)$ & $22.73(1.26)$ & $8.94(0.59)$ \\
\hline & Fishes & $2.39(0.12)$ & $2.84(0.18)$ & $2.27(0.12)$ & $4.88(0.32)$ \\
\hline & Shrimps & $3.73(0.19)$ & - & $2.27(0.12)$ & - \\
\hline & Blue crab & - & $2.5(0.16)$ & - & $1.22(0.08)$ \\
\hline & Goby & $0.35(0.02)$ & - & $2.27(0.12)$ & - \\
\hline & Mysid & - & $0.01(0)$ & - & $2.44(0.16)$ \\
\hline
\end{tabular}

Mysid shrimps constituted the most frequent prey item encountered in control fish, along with amphipods, isopods, and other unidentified crustaceans. Polychaetes were encountered fairly often in control fish $(\% F>10)$, but snapping shrimp were not found at all. Control fish $\% W$ was spread amongst 3 major prey groups: mysids, polychaetes, and amphipodsisopods. Overall silver perch diet composition as measured by both $\% F$ and $\% W$ differed significantly by habitat type, but the variation explained by habitat type was limited (1-way PERMANOVA, \%F: pseudo- $\mathrm{R}^{2}=0.09, F=1.83, \mathrm{p}=0.07 ; \% W$ : pseudo- $\mathrm{R}^{2}=$ $0.097, F=1.84, \mathrm{p}=0.07$ ). SIMPER results indicated unidentified crustaceans (dissimilarity percentage $=$
0.16 ), mysids (dissimilarity percentage $=0.14$ ), snapping shrimp (dissimilarity percentage $=0.11$ ), and polychaete worms (dissimilarity percentage $=0.10$ ) contributed most prominently to observed dissimilarity between the 2 habitat groups. SIMPER analysis for $\% W$ suggested the same suite of prey contributed most to the observed dissimilarity.

For spot, polychaete worms were the primary prey type consumed from both habitat types (Table 6). Copepods (primarily Harpacticoida) were also frequently encountered, though to a lesser degree in control habitat $(\% F=22)$ than reef habitat $(\% F=44)$. Other small crustaceans were encountered infrequently, and tunicates (Molgula sp.) were recovered 
from approximately $10 \%$ of spot stomachs from oyster reefs, but from very few control fish stomachs $(\% F<0.2$; Table 6$)$. One-way PERMANOVA results for both $\% F$ and $\% W$ indicated a very limited role of habitat in explaining overall differences between habitats ( $\% F$ : pseudo-R ${ }^{2}=0.03, F=2.01$, p $=0.11$; $\% W$ : pseudo-R $\mathrm{R}^{2}=0.04, F=2.31, \mathrm{p}=0.07$ ). SIMPER analysis suggested that these dissimilarities were primarily attributable to polychaetes (dissimilarity percentage $=0.16$ ), copepods (dissimilarity percentage $=$ 0.16 ), and unidentifiable material (dissimilarity percentage $=0.12$ ) .

Croaker collected from both reef and control habitats foraged most frequently on polychaete worms, and polychaete worms contributed nearly $60 \% W$ in both habitat types (Table 6). Unidentified bivalves (reef habitat) and clams (both reef and control habitats) were consumed frequently as well $(\% F>15)$. Clams contributed prominently to the diet by weight of control-caught fish $(\% W>30)$. Overall diet composition did not vary significantly between habitat types for either $\% F$ (1-way PERMANOVA; pseudo- ${ }^{2}$ $=0.02, F=0.051, \mathrm{p}=0.78)$ or $\% W\left(\right.$ pseudo $-\mathrm{R}^{2}<0.01$, $F=0.206, \mathrm{p}=0.96)$.

\subsection{Daily consumption}

The estimated mean $( \pm \mathrm{SE})$ daily consumption rate for silver perch in July $(0.023 \pm 0.01 \mathrm{~g}$ of prey consumed $g$ of predator ${ }^{-1} \mathrm{~d}^{-1}$ ) (Fig. 4) in oyster reef habi-

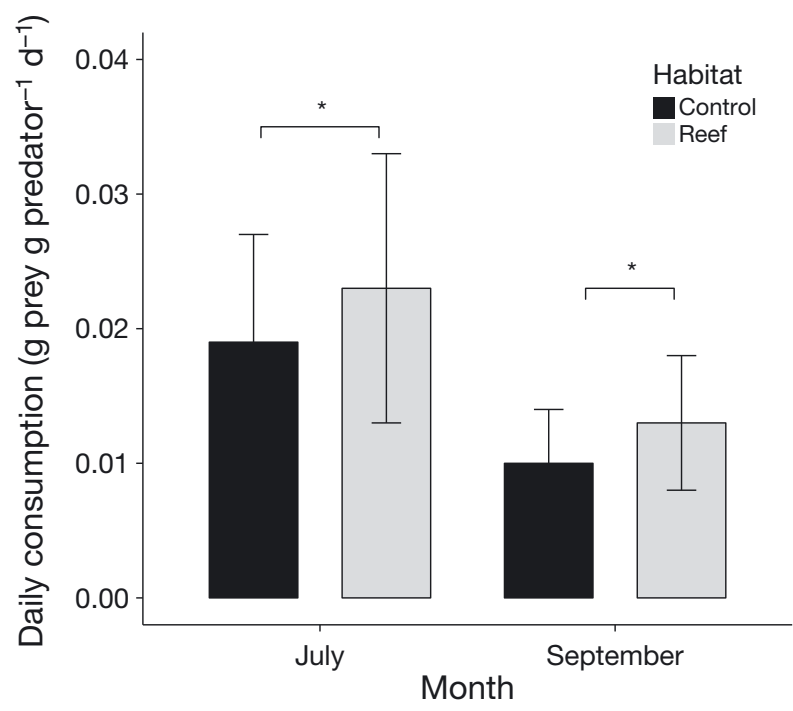

Fig. 4. Mean $( \pm 1 \mathrm{SE})$ daily consumption rate of silver perch Bairdiella chrysoura, estimated by habitat type and month. $\left({ }^{*}\right)$ indicates a significant difference $(\alpha=0.1)$ in mean estimated consumption rate between habitat types when evaluated with non-parametric Mann-Whitney $U$-test tat exceeded the estimated rate in control habitat by approximately $20 \%\left(0.019 \pm 0.01 \mathrm{~g}\right.$ prey $\mathrm{g}$ predator $^{-1}$ $\mathrm{d}^{-1}$ ). The September estimate of mean daily consumption rate in oyster reef habitat $(0.013 \pm<0.01 \mathrm{~g}$ prey $g$ predator ${ }^{-1} \mathrm{~d}^{-1}$ ) also exceeded the control habitat estimate $\left(0.010 \pm<0.01 \mathrm{~g}\right.$ prey $\mathrm{g}$ predator $\left.{ }^{-1} \mathrm{~d}^{-1}\right)$. Differences between habitat types for both months were statistically significant (July $W=638940$, p < 0.01; September $W=644920, \mathrm{p}<0.01$ ). On an individual fish basis, reef habitat estimates of total consumption were also greater than control estimates in both July (reef: $0.62 \mathrm{~g}$ of prey consumed fish ${ }^{-1} \mathrm{~d}^{-1}$; control: $0.49 \mathrm{~g}$ prey fish ${ }^{-1} \mathrm{~d}^{-1}$ ) and September (reef: $0.29 \mathrm{~g}$ prey fish $\mathrm{d}^{-1} \mathrm{~d}^{-1}$ control: $0.23 \mathrm{~g}$ prey $\mathrm{fish}^{-1} \mathrm{~d}^{-1}$ ).

\section{DISCUSSION}

Contrary to initial expectations and previous findings in a wide variety of systems from North Carolina to the Gulf of Mexico (Lenihan et al. 2001, Humphries \& La Peyre 2015), large (3-5 ha) subtidal oyster reefs constructed nearly a decade ago and supporting high densities (49.1-74.8 ind. $\mathrm{m}^{-2}$ ) of oysters harbored a similar fish community and fewer fish overall compared with unstructured, unrestored bottom areas in the LRS. Significantly larger fish were collected from restored oyster reefs, however, indicating an influence of restored oyster reef habitat on fish size distribution within the LRS. One relatively abundant species, silver perch, exhibited significantly enhanced stomach fullness and daily consumption rates in restored oyster reef habitat, suggesting reef restoration can promote the feeding ecology of an important forage fish (Latour et al. 2008, Sobocinski \& Latour 2015). Our study provides new insight into the role that large, restored oyster reefs may play as fish habitat and offers implications for future oyster reef habitat research and restoration.

\subsection{Fish abundance, diversity, and size}

Our study is not alone in finding equivalent or reduced catches of fish, especially of mobile or transient fish, on oyster reefs compared to unstructured habitat (e.g. Pierson \& Eggleston 2014), and several factors may explain our findings. Landscape context, or the location of a particular habitat 'patch' within the broader estuarine 'mosaic' of habitat types, is known to drive fish use of estuarine and coastal habitats (Nagelkerken et al. 2015). We did not evaluate the role of landscape context, but other studies sug- 
gest landscape-level factors, like proximity to adjacent habitats or the availability of movement corridors, play a strong role in determining fish abundance (Grabowski et al. 2005, Geraldi et al. 2009), and that this influence can persist for many years following restoration (Ziegler et al. 2018). In addition, the LRS fish community, like many estuarine systems along the US mid-Atlantic coast, is dominated by generalist species capable of utilizing various habitat types opportunistically (Murdy et al. 1997, Buchheister \& Latour 2015). Other nearby habitats likely to harbor both juvenile and adult fishes in the LRS include fringing salt marsh, tidal creeks, and cageaquaculture operations (Minello et al. 2003, Powers et al. 2007). Methodologically, this study employed a monthly survey that occurred only during daytime hours to evaluate fish abundance. Many fish are more active at dusk, night, and dawn than in the daytime, and may be less vulnerable to a daytime survey (Rountree \& Able 2007). Gill nets are also highly sizeselective, and even with multi-panel nets, many fish may have remained untargeted. In addition, we typically set our gill nets well within the confines of the large reef area, and thus did not explore potential variability due to habitat edge effects (Boström et al. 2011).

Variation in site-level characteristics such as size or average water depth among our 3 study reefs may also have contributed to the observed variability in fish abundance. We initially accounted for unmeasured site-level variation by including site as a random effect term in 2 possible statistical models (Table 2). These tended to be ranked lower (via $\mathrm{AIC}_{\mathrm{c}}$ ) than other models, but were often within the top 5 possibilities, suggesting site-level characteristics may play a role in explaining fish abundance (Table S2). When overall CPUE was specifically compared among the 3 study reefs (Fig. S1), the 2 deeper reefs tended to have higher catch rates relative to the shallower reef. One possibility is that depth interacted with our sample gear to influence catchability, but another is that fish tended to be more abundant on reefs of greater depth. Water depth and reef height interacted to alter fish abundance on North Carolina reefs impacted by hypoxia (Lenihan et al. 2001), but it is unclear whether the differences in depth observed among the subtidal reefs here $(\sim 0.6-0.9 \mathrm{~m})$ played a role in determining fish abundance under generally normoxic conditions. We suggest further study of restored reefs across a depth gradient ranging from intertidal to subtidal is warranted to better inform the future placement of restoration reefs intended to promote fish habitat use.
Beyond habitat type, water temperature also emerged as an important and positive predictor of relative fish abundance. Temperature is a primary determinant of fish habitat quality, and fish abundance in Chesapeake Bay increases in spring and summer as temperatures warm, estuarine-dependent and coastal species move inshore and to shallow waters, and new recruits arrive in the estuary (Murdy et al. 1997). The summertime peak in relative abundance suggests the monthly survey captured the strong seasonality of the Chesapeake Bay fish assemblage.

Though an increase in fish abundance or diversity was not observed, the mean size of fish collected from restored oyster reefs in the LRS was significantly greater, both overall and on a species-specific basis. Our results, from large restored reefs in a polyhaline estuary, are consistent with several other studies undertaken on smaller reefs in different biophysical conditions. Harding \& Mann (2001b), sampling approximately $4 \mathrm{yr}$ post-reef construction, observed larger individuals from several species, including Atlantic croaker, associated with a 0.9 ha created oyster reef in a lower-salinity Chesapeake Bay sub-estuary (Karp et al. 2018). Simonsen \& Cowan (2013) surveyed a small $(<0.5 \mathrm{ha})$ limestone cobble mimic oyster reef in Barataria Bay, Louisiana, and found significantly larger Atlantic croaker and spotted seatrout Cynoscion nebulosus at the reef compared to nearby mud bottom. The consistency of our findings with these from disparate systems is notable and suggests a relatively strong influence of oyster reef presence on size distribution of Atlantic croaker and other fishes, but the mechanism behind this pattern is unclear. Harding \& Mann (2001b) hypothesized increased abundance or size of fish at oyster reefs is due to the increased availability of high-quality prey, but this is not clearly supported by our results. Atlantic croaker did not display significant habitat-related differences in stomach fullness or diet composition, and croaker stomach contents were composed of prey items generally available in both habitat types. Due to a limited sample size we were unable to examine croaker foraging metrics by size class, which we recommend in the future to shed light on the statistically significant length difference observed here. Silver perch, on the other hand, were both significantly larger and showed significantly greater stomach fullness on oyster reefs compared to unstructured bottom; together with diet composition and estimated daily consumption rate (discussed below), this suggests use of restored reefs as a foraging ground. Spot showed the smallest difference between habitats in terms of mean size, and it is unclear whether this dif- 
ference was biologically meaningful. Fewer spot were found on restored oyster reefs compared to control sites, and reef-caught spot exhibited lower levels of stomach fullness. Field and lab studies suggest that food has a strong effect on spot distribution in estuaries, even stronger than the effect of predators or predation risk (Miltner et al. 1995, Craig et al. 2007). Given the importance of infaunal organisms in spot diet, and the availability of those prey in unstructured, soft-sediments (Lawless \& Seitz 2014), the combination of greater prey availability or increased foraging efficiency in control habitats may drive the observed pattern in the relative abundance of spot.

\subsection{Fish diet composition}

Many prey items found in the stomach contents of fish collected on oyster reefs, including epibenthic crustaceans such as snapping shrimp, resident oyster reef fishes, and tunicates, are also present in high abundance on reefs in the LRS (Karp et al. 2018). The presence of these items in fish gut contents provides some evidence that the large-scale restored reefs in the LRS are likely linked to mobile fishes via provision of prey for consumption nearly a decade postconstruction (though not conclusive due to the mobile nature of the study species and the related widespread occurrence of these prey types). This finding is similar to that demonstrated previously on smaller reefs in a lower-salinity system in Chesapeake Bay, and in other estuarine systems in the Gulf of Mexico and Southeast Atlantic (Harding \& Mann 2001a, Yeager \& Layman 2011, Abeels et al. 2012). Connections to oyster-reef-related prey were most apparent for silver perch; of particular importance to reef-caught silver perch diet were big-clawed snapping shrimp Alpheus heterochaelis. Reported food sources for $A$. heterochaelis include small invertebrates, detritus, benthic microalgae, and particulate organic matter (Abeels et al. 2012). Silver perch, in turn, are frequently consumed by piscivores, such as summer flounder (Latour et al. 2008, Sobocinski \& Latour 2015). Thus, consumption of $A$. heterochaelis by silver perch may represent an important conduit of basal secondary production to higher trophic levels in the LRS from the large-scale restored oyster reefs. In Florida, snapping shrimp have also been found to be an important oyster-reef-related prey item for species such as sheepshead Archosargus probatocephalus, common snook Centropomus undecimalis, ladyfish Elops saurus, grey snapper, and red drum Sciaenops ocellatus (Wasno 2014).
Mud crabs (Xanthidae) make up a substantial portion of macrofauna biomass on oyster reefs in the LRS (Karp et al. 2018), but crabs contributed little to either $\% F$ or $\% W$ of silver perch, croaker, or spot. In other systems, transient fish consumed mud crabs, with estimates as high as $40 \%$ diet by weight for Atlantic croaker collected from a constructed oyster reef in Barataria Bay, Louisiana (Simonsen \& Cowan 2013). Underrepresentation of mud crabs in fish diets may suggest restored reef macrofauna are not equally available to all predators in the system, but could also indicate that other prey items (e.g. polychaete worms) were more abundant or easier to access for the fish species and size classes studied here. Regardless, the fact that the significant macrofaunal biomass available on oyster reefs may not be taken advantage of by all species and size classes in a system is an important note to consider when evaluating the available prey base enhanced by oyster reef restoration.

More generally, a range of benthic prey dominated the diet of silver perch, spot, and croaker, regardless of habitat, highlighting the importance of benthic productivity to the trophic ecology of the sciaenids studied. Studies of fish-foraging habits in the Chesapeake Bay mainstem and in other shallow-water bay habitats also attribute the majority of fish consumption to non-pelagic prey types (Ihde et al. 2015). Polychaete worms were important in the diets of all 3 sciaenids in both habitat types, and are routinely identified as a dominant prey group for demersal fishes (Buchheister \& Latour 2015). The presence of polychaetes in reef-caught fish stomachs may indicate habitat connectivity between nearby soft-sediments and restored reefs; fishes may be foraging for polychaetes in adjacent soft bottom areas, then moving back to reefs for refuge after feeding, a tactic identified for many reef-associated fishes but less well studied in oyster reef environments (Langlois et al. 2005). Further research would help shed light on this pattern, and could provide insight into optimizing the placement of restored reefs in locations that maximize connectivity with nearby soft-bottom foraging habitat.

Alternatively, sciaenids may be foraging on polychaetes in abundance on the restored oyster reefs themselves, as restored oyster reefs in the LRS support polychaete worms at densities equal to or greater than those in surrounding soft-sediments (Lawless \& Seitz 2014, Karp et al. 2018). Combining traditional stomach content analysis with DNA-based approaches may assist future studies in determining prey habitat origin by providing fine-scale prey species resolution (Carreon-Martinez et al. 2011). Stable isotope analy- 
ses, when used in conjunction with stomach content evaluation, can also prove useful in identifying key trophic links in coastal systems (e.g. Quan et al. 2012). Similarly, future studies combining diet analyses with estimates of home range and site fidelity (e.g. tagging or telemetry) would help us better understand the links between fish diet, consumption, and discrete habitat types. Estimates of site fidelity, home range, and time spent in restored oyster reef habitat are lacking for many species of fish, especially those of the size range in our study (but see George 2007, Fodrie et al. 2015). Future studies that specifically estimate site fidelity or fish home ranges before and after oyster reef construction may prove valuable in evaluating restoration success, especially given that fidelity to a particular site or creek is hypothesized to relate to habitat quality (Garwood et al. 2019). Additionally, in the context of stomach fullness and diet analysis, a factor that we did not examine in detail is tidal stage a known influence on fish habitat use, behavior, and foraging (e.g. for silver perch; Kleypas \& Dean 1983). We suggest future research could examine the significance of tidal stage on fish habitat use of subtidal reefs in estuarine systems (like the LRS) where fish may make frequent forays between subtidal and intertidal areas across the tidal cycle.

\subsection{Silver perch consumption}

Bioenergetics models linking restored habitats to fishes are necessary to develop quantitative predictions regarding the impacts of habitat restoration on fish productivity (NASEM 2017), but few studies have explicitly estimated the required model parameters in the field. Our field-based daily consumption estimates, unique in the context of oyster reef and habitat restoration science, predict that a hypothetical silver perch foraging exclusively in restored oysterreef habitat will consume a greater amount of prey than a similar fish foraging in unstructured bottom habitat. By positively influencing consumption rates of an ecologically important forage fish like silver perch, large, subtidal restored oyster reefs like those constructed in the LRS may indirectly promote enhanced productivity of higher trophic levels in Chesapeake Bay and other estuarine systems. The amount of prey consumed by an individual has been positively linked to increased growth rates in a number of fish species (Kennedy et al. 2008), but additional research is needed to investigate whether increased consumption in oyster reef habitat translates into increased growth rates of individual silver perch.
Growth rates are influenced by a range of factors besides consumption rate, including temperature, reproductive state, activity rate, prey energy density, and body size (Hewett \& Kraft 1993).

Field-based estimates of daily consumption by other sciaenid fishes have reported values similar to this study $(0.3-2.0 \%$ body weight). Daily consumption of age $0-1$ red drum in North Carolina marsh creeks was estimated between $1.0-4.0 \%$ total body weight, and whitemouth croaker Micropogonias furnieri consumed between 0.9 and $5.3 \%$ body weight in a Brazilian estuary (Figueiredo \& Vieira 2005, Facendola \& Scharf 2012). By contrast, the estimates of silver perch daily consumption by habitat type from this study are low relative to rates estimated using a calibrated bioenergetics model for young-of-the-year silver perch inhabiting Chesapeake Bay seagrass beds $($ mean $=14.5 \%$, range $=6-38 \%$; Sobocinski \& Latour 2015). Field-based consumption estimates tend to be biased low; in this study, small numbers of fish collected and a limited number of diel sampling events may have influenced our estimates. Additionally, the calibrated bioenergetics model in Sobocinski \& Latour (2015) was developed for silver perch ranging in size from 22-132 mm TL. Our estimated consumption rate was based on a narrower size range of larger individuals (109-152 mm TL). Weight-specific consumption rates tend to decline as fish grow larger (Facendola \& Scharf 2012), which may explain some of the difference observed between studies.

\section{CONCLUSIONS}

Restored oyster reefs constructed nearly a decade prior to the present study in the LRS are utilized by both juvenile and adult stages of coastal and estuarine mobile fishes, and these restored reefs influence the size distribution and foraging patterns of mobile estuarine fishes. Fish species and size-classes that select for reef-associated prey types may particularly benefit from oyster reef restoration. Our results suggest large subtidal oyster reefs like those in the LRS areas may enhance trophic support for key forage fish, or may promote the aggregation of larger fishes, a potential benefit for recreational anglers. By evaluating a large-scale restoration project several years post-construction, and by generating habitat-based estimates of consumption for silver perch, this study advances knowledge of restoration ecology and provides intriguing results that enhance our understanding of the links between oyster reefs, fisheries production, and ecosystem services. 
Acknowledgements. Research funding was provided by NOAA's Chesapeake Bay Office, Oyster Reef Ecosystem Services Grant NA14NMF4570288, awarded to R.D.S. and Romuald Lipcius. Additional funding was provided to B.W.P. from the Virginia Institute of Marine Science (VIMS) Office of Academic Studies and the VIMS Foundation. The authors thank the staff and students of the Community Ecology (R.D.S.) and Marine Conservation Biology (R. Lipcius) labs, as well as 2 interns from the Virginia Governor's School Program for their help in the field and lab. We also thank Jenny Dreyer for assistance with gut content identification, and VIMS Eastern Shore Laboratory staff for gill net sampling guidance. We especially thank Rob Latour for help with daily consumption estimations. Lastly, the authors thank the members of B.W.P.'s thesis committee (Mary Fabrizio, Rob Latour, and M. Lisa Kellogg) for their edits to earlier versions of the manuscript, as well as 3 anonymous reviewers for their comments. This paper is Contribution No. 3839 of the Virginia Institute of Marine Science, William \& Mary, and Contribution No. 1876 of the Belle W. Baruch Institute for Marine and Coastal Sciences.

\section{LITERATURE CITED}

Abeels HA, Loh AN, Volety AK (2012) Trophic transfer and habitat use of oyster Crassostrea virginica reefs in southwest Florida, identified by stable isotope analysis. Mar Ecol Prog Ser 462:125-142

Anderson MJ (2001) A new method for non-parametric multivariate analysis of variance. Austral Ecol 26:32-46

Bates D, Maechler M, Bolker B, Walker S (2015) Fitting linear mixed-effects models using lme4. J Stat Softw 67:1-48

* Beck MW, Heck KL Jr, Able KW, Childers DL and others (2001) The identification, conservation, and management of estuarine and marine nurseries for fish and invertebrates. Bioscience 51:633-641

Beck MW, Brumbaugh RD, Airoldi L, Carranza A and others (2011) Oyster reefs at risk and recommendations for conservation, restoration, and management. Bioscience 61: 107-116

Borja Á, Dauer DM, Elliott M, Simenstad CA (2010) Mediumand long-term recovery of estuarine and coastal ecosystems: patterns, rates and restoration effectiveness. Estuaries Coasts 33:1249-1260

Boström C, Pittman SJ, Simenstad C, Kneib RT (2011) Seascape ecology of coastal biogenic habitats: advances, gaps, and challenges. Mar Ecol Prog Ser 427:191-217

Buchheister A, Latour RJ (2015) Diets and trophic-guild structure of a diverse fish assemblage in Chesapeake Bay, USA: trophic ecology of Chesapeake Bay fishes. J Fish Biol 86:967-992

Buckel JA, Fogarty MJ, Conover DO (1999) Foraging habits of bluefish, Pomatomus saltatrix, on the US east coast continental shelf. Fish Bull 97:758-775

Burnham KP, Anderson DR (2002) Model selection and multi-model inference: a practical information-theoretic approach. Springer-Verlag, New York, NY

Carreon-Martinez L, Johnson TB, Ludsin SA, Heath DD (2011) Utilization of stomach content DNA to determine diet diversity in piscivorous fishes. $\mathrm{J}$ Fish Biol 78: 1170-1182

Clarke KR, Warwick RM (2001) Change in marine communities: an approach to statistical analysis and interpretation, $2^{\text {nd }}$ edn. PRIMER-E, Plymouth
Coen LD, Brumbaugh RD, Bushek D, Grizzle R and others (2007) Ecosystem services related to oyster restoration. Mar Ecol Prog Ser 341:303-307

* Craig JK, Rice JA, Crowder LB, Nadeau DA (2007) Densitydependent growth and mortality in an estuary-dependent fish: an experimental approach with juvenile spot Leiostomus xanthurus. Mar Ecol Prog Ser 343:251-262

Durbin EG, Durbin AG, Langton RW, Bowman RE (1983) Stomach contents of silver hake, Merluccius bilinearis, and Atlantic cod, Gadus morhua, and estimation of their daily rations. Fish Bull 81:437-454

Facendola JJ, Scharf FS (2012) Seasonal and ontogenetic variation in the diet and daily ration of estuarine red drum as derived from field-based estimates of gastric evacuation and consumption. Mar Coast Fish 4:546-559

Figueiredo GM, Vieira JP (2005) Diel feeding, daily food consumption and the predatory impact of whitemouth croaker (Micropogonias furnieri) in an estuarine environment. Mar Ecol 26:130-139

Fodrie FJ, Yeager LA, Grabowski JH, Layman CA, Sherwood GD, Kenworthy MD (2015) Measuring individuality in habitat use across complex landscapes: approaches, constraints, and implications for assessing resource specialization. Oecologia 178:75-87

Garwood JA, Allen DM, Kimball ME, Boswell KM (2019) Site fidelity and habitat use by young-of-the-year transient fishes in salt marsh intertidal creeks. Estuaries Coasts 42:1387-1396

George GJ (2007) Acoustic tagging of black drum on Louisiana oyster reefs: movements, site fidelity, and habitat use. PhD dissertation. Louisiana State University, Baton Rouge, LA

Geraldi NR, Powers SP, Heck KL, Cebrian J (2009) Can habitat restoration be redundant? Response of mobile fishes and crustaceans to oyster reef restoration in marsh tidal creeks. Mar Ecol Prog Ser 389:171-180

* Grabowski JH, Hughes AR, Kimbro DL, Dolan MA (2005) How habitat setting influences restored oyster reef communities. Ecology 86:1926-1935

* Harding JM, Mann R (2001a) Diet and habitat use by bluefish, Pomatomus saltatrix, in a Chesapeake Bay estuary. Environ Biol Fishes 60:401-409

Harding JM, Mann R (2001b) Oyster reefs as fish habitat: opportunistic use of restored reefs by transient fishes. J Shellfish Res 20:951-959

Harding JM, Mann R (2003) Influence of habitat on diet and distribution of striped bass (Morone saxatilis) in a temperate estuary. Bull Mar Sci 72:841-851

Harwell HD, Posey MH, Alphin TD (2011) Landscape aspects of oyster reefs: effects of fragmentation on habitat utilization. J Exp Mar Biol Ecol 409:30-41

*Hewett SW, Kraft CE (1993) The relationship between growth and consumption: comparisons across fish populations. Trans Am Fish Soc 122:814-821

* Humphries AT, La Peyre MK (2015) Oyster reef restoration supports increased nekton biomass and potential commercial fishery value. PeerJ 3:e1111

Ihde T, Houde E, Bonzek C, Franke E (2015) Assessing the Chesapeake Bay forage base: existing data and research priorities. STAC Publication 15-005. Chesapeke Bay Program Scientific and Technical Advisory Committee, Edgewater, MD

Karp MA, Seitz RD, Fabrizio MC (2018) Faunal communities on restored oyster reefs: effects of habitat complexity and environmental conditions. Mar Ecol Prog Ser 590:35-51 
Kennedy BP, Nislow KH, Folt CL (2008) Habitat-mediated foraging limitations drive survival bottlenecks for juvenile salmon. Ecology 89:2529-2541

Kleypas J, Dean JM (1983) Migration and feeding of the predatory fish, Bairdiella chrysoura Lacepede, in an intertidal creek. J Exp Mar Biol Ecol 72:199-209

La Peyre MK, Humphries AT, Casas SM, La Peyre JF (2014) Temporal variation in development of ecosystem services from oyster reef restoration. Ecol Eng 63:34-44

Langlois TJ, Anderson MJ, Babcock RC (2005) Reef-associated predators influence adjacent soft-sediment communities. Ecology 86:1508-1519

Latour RJ, Gartland J, Bonzek CF, Johnson RA (2008) The trophic dynamics of summer flounder (Paralichthys dentatus) in Chesapeake Bay. Fish Bull 106:47-57

Lawless AS, Seitz RD (2014) Effects of shoreline stabilization and environmental variables on benthic infaunal communities in the Lynnhaven River System of Chesapeake Bay. J Exp Mar Biol Ecol 457:41-50

Lenihan HS, Peterson CH, Byers JE, Grabowski JH, Thayer GW, Colby DR (2001) Cascading of habitat degradation: oyster reefs invaded by refugee fishes escaping stress. Ecol Appl 11:764-782

Link JS, Garrison LP, Almeida FP (2002) Ecological interactions between elasmobranchs and groundfish species on the northeastern US continental shelf. I. Evaluating predation. N Am J Fish Manage 22:550-562

Lipcius RN, Burke RP, McCulloch DN, Schreiber SJ, Schulte DM, Seitz RD, Shen J (2015) Overcoming restoration paradigms: value of the historical record and metapopulation dynamics in native oyster restoration. Front Mar Sci 2:65

Maunder MN, Punt AE (2004) Standardizing catch and effort data: a review of recent approaches. Fish Res 70:141-159

McCoy E, Borrett SR, LaPeyre MK, Peterson BJ (2017) Estimating the impact of oyster restoration scenarios on transient fish production: oyster restoration impact on transient fish. Restor Ecol 25:798-809

* Miltner RJ, Ross SW, Posey MH (1995) Influence of food and predation on the depth distribution of juvenile spot (Leiostomus xanthurus) in tidal nurseries. Can J Fish Aquat Sci 52:971-982

Minello TJ, Able KW, Weinstein MP, Hays CG (2003) Salt marshes as nurseries for nekton: testing hypotheses on density, growth and survival through meta-analysis. Mar Ecol Prog Ser 246:39-59

Murdy EO, Birdsong RS, Musick JA (1997) Fishes of Chesapeake Bay. Smithsonian Institution Press, Washington, DC

*Nagelkerken I, Sheaves M, Baker R, Connolly RM (2015) The seascape nursery: a novel spatial approach to identify and manage nurseries for coastal marine fauna. Fish Fish 16:362-371

NASEM (National Academies of Sciences, Engineering, and Medicine) (2017) Effective monitoring to evaluate ecological restoration in the Gulf of Mexico. The National Academies Press, Washington, DC

Oksanen J, Blanchet FG, Friendly M, Kindt R and others (2019) vegan: community ecology package 2.5-4. https:// CRAN.R-project.org/package=vegan

Peterson $\mathrm{CH}$, Summerson HC, Thomson E, Lenihan HS and others (2000) Synthesis of linkages between benthic and fish communities as a key to protecting essential fish habitat. Bull Mar Sci 66:759-774

Pierson KJ, Eggleston DB (2014) Response of estuarine fish to large-scale oyster reef restoration. Trans Am Fish Soc 143:273-288

Powers MJ, Peterson CH, Summerson HC, Powers SP (2007) Macroalgal growth on bivalve aquaculture netting enhances nursery habitat for mobile invertebrates and juvenile fishes. Mar Ecol Prog Ser 339:109-122

Fowers SP, Grabowski JH, Peterson CH, Lindberg WJ (2003) Estimating enhancement of fish production by offshore artificial reefs: uncertainty exhibited by divergent scenarios. Mar Ecol Prog Ser 264:265-277

Quan W, Humphries AT, Shi L, Chen Y (2012) Determination of trophic transfer at a created intertidal oyster (Crassostrea ariakensis) reef in the Yangtze River Estuary using stable isotope analyses. Estuaries Coasts 35:109-120

R Core Team (2016) R: a language and environment for statistical computing. R Foundation for Statistical Computing, Vienna. www.r-project.org

* Rodney WS, Paynter KT (2006) Comparisons of macrofaunal assemblages on restored and non-restored oyster reefs in mesohaline regions of Chesapeake Bay in Maryland. J Exp Mar Biol Ecol 335:39-51

* Rountree RA, Able KW (2007) Spatial and temporal habitat use patterns for salt marsh nekton: implications for ecological functions. Aquat Ecol 41:25-45

* Scharf FS, Manderson JP, Fabrizio MC (2006) The effects of seafloor habitat complexity on survival of juvenile fishes: species-specific interactions with structural refuge. J Exp Mar Biol Ecol 335:167-176

Simonsen KA, Cowan JH (2013) Effects of an inshore artificial reef on the trophic dynamics of three species of estuarine fish. Bull Mar Sci 89:657-676

* Sobocinski KL, Latour RJ (2015) Trophic transfer in seagrass systems: estimating seasonal production of an abundant seagrass fish, Bairdiella chrysoura, in lower Chesapeake Bay. Mar Ecol Prog Ser 523:157-174

* Stunz GW, Minello TJ (2001) Habitat-related predation on juvenile wild-caught and hatchery-reared red drum Sciaenops ocellatus (Linnaeus). J Exp Mar Biol Ecol 260: $13-25$

K Sutton TM, Cyterski MJ, Ney JJ, Duval MC (2004) Determination of factors influencing stomach content retention by striped bass captured using gillnets. J Fish Biol 64: 903-910

*Venables WN, Dichmont CM (2004) GLMs, GAMs and GLMMs: an overview of theory for applications in fisheries research. Fish Res 70:319-337

Venables WN, Ripley BD (2002) Modern applied statistics with S. Springer, New York, NY

Wasno RM (2014) Investigation of trophic transfer from oyster reefs to predatory fishes in southwest Florida. MSc thesis. Florida Gulf Coast University, Fort Myers, FL

*Yeager LA, Layman CA (2011) Energy flow to two abundant consumers in a subtropical oyster reef food web. Aquat Ecol 45:267-277

Z Zhao Q, Bai J, Huang L, Gu B, Lu Q, Gao Z (2016) A review of methodologies and success indicators for coastal wetland restoration. Ecol Indic 60:442-452

Kiegler SL, Grabowski JH, Baillie CJ, Fodrie FJ (2018) Effects of landscape setting on oyster reef structure and function largely persist more than a decade post-restoration. Restor Ecol 26:933-942

zu Ermgassen PSE, Grabowski JH, Gair JR, Powers SP (2016) Quantifying fish and mobile invertebrate production from a threatened nursery habitat. J Appl Ecol 53: 596-606 